\title{
ADP-Ribosylation Factor GTPase-Activating Protein 3
}

National Cancer Institute

\section{Source}

National Cancer Institute. ADP-Ribosylation Factor GTPase-Activating Protein 3. NCI

Thesaurus. Code C150174.

ADP-ribosylation factor GT Pase-activating protein 3 (516 aa, $\sim 57 \mathrm{kDa}$ ) is encoded by the human ARFGAP3 gene. This protein is involved in the promotion of ADP-ribosylation factor 1 GT Pase activity. 